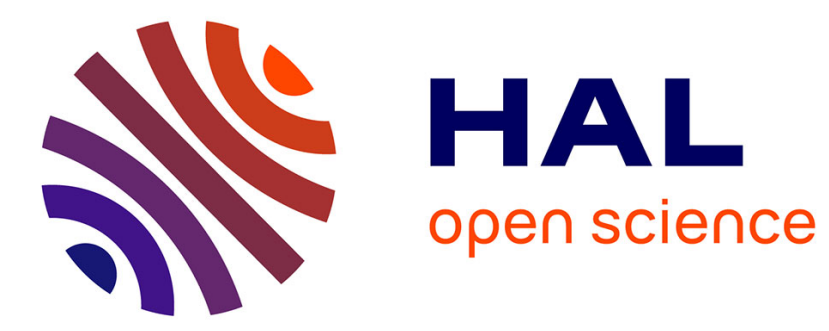

\title{
Measurements of molecular hydrogen and carbon monoxide on the Trainou tall tower
}

Camille Yver, Martina Schmidt, Philippe Bousquet, Michel Ramonet

\section{To cite this version:}

Camille Yver, Martina Schmidt, Philippe Bousquet, Michel Ramonet. Measurements of molecular hydrogen and carbon monoxide on the Trainou tall tower. Tellus B - Chemical and Physical Meteorology, 2011, 63 (1), pp.52-63. 10.1111/j.1600-0889.2010.00520.x . hal-03116009

\section{HAL Id: hal-03116009 \\ https://hal.science/hal-03116009}

Submitted on 21 Jun 2021

HAL is a multi-disciplinary open access archive for the deposit and dissemination of scientific research documents, whether they are published or not. The documents may come from teaching and research institutions in France or abroad, or from public or private research centers.
L'archive ouverte pluridisciplinaire $\mathbf{H A L}$, est destinée au dépôt et à la diffusion de documents scientifiques de niveau recherche, publiés ou non, émanant des établissements d'enseignement et de recherche français ou étrangers, des laboratoires publics ou privés. 


\section{Tellus B: Chemical and Physical Meteorology}

\section{Measurements of molecular hydrogen and carbon monoxide on the Trainou tall tower}

\section{Camille Yver, Martina Schmidt, Philippe Bousquet \& Michel Ramonet}

To cite this article: Camille Yver, Martina Schmidt, Philippe Bousquet \& Michel Ramonet (2011) Measurements of molecular hydrogen and carbon monoxide on the Trainou tall tower, Tellus B: Chemical and Physical Meteorology, 63:1, 52-63, DOI: 10.1111/j.1600-0889.2010.00520.x

To link to this article: https://doi.org/10.1111/j.1600-0889.2010.00520.x

$$
\begin{aligned}
& \text { (c) } 2011 \text { The Author(s). Published by Taylor \& } \\
& \text { Francis. }
\end{aligned}
$$

\section{曲 Published online: 18 Jan 2017.}

Submit your article to this journal $\pi$

III Article views: 78

Q View related articles $\sqsubset$

th

Citing articles: 1 View citing articles $₫$ 


\title{
Measurements of molecular hydrogen and carbon monoxide on the Trainou tall tower
}

\author{
By CAMILLE YVER ${ }^{1 *}$, MARTINA SCHMIDT ${ }^{1}$, PHILIPPE BOUSQUET ${ }^{1,2}$ \\ and MICHEL RAM ONET ${ }^{1}, \quad{ }^{1}$ Laboratoire des Sciences du Climat et de l'Environnement, IPSL, CEA, UVSQ, \\ CNRS, Gif-sur-Yvette 91191, France; ${ }^{2}$ Université de Versailles Saint Quentin en Yvelines, 78035 Versailes, France
}

(Manuscript received 28 June 2010; in final form 2 November 2010)

\begin{abstract}
We present 2 yr (October 2008 to September 2010) of in situ measurements of molecular hydrogen $\left(\mathrm{H}_{2}\right)$ and carbon monoxide (CO) sampled at the tall tower of Trainou, France $\left(47.96^{\circ} \mathrm{N}, 02.11^{\circ} \mathrm{E}, 131\right.$ masl, sampling height: 50, 100 and $180 \mathrm{~m})$. Radon-222 ( $\left.{ }^{222} \mathrm{Rn}\right)$ measurements were added in May 2009. Background seasonal cycles, based on afternoon values, exhibit an amplitude of 45 and $60 \mathrm{ppb}$ for $\mathrm{H}_{2}$ and $\mathrm{CO}$, respectively, for the three different heights (50, 100 and $180 \mathrm{~m}$ above ground). The vertical gradient also shows seasonal variations with a maximum (during the night) of 20 and $45 \mathrm{ppb}$ for $\mathrm{H}_{2}$ and $\mathrm{CO}$, respectively. We also observe diurnal cycles for $\mathrm{H}_{2}$ and $\mathrm{CO}$ for the three different heights. In the afternoon, the mixing ratios at the three different heights are similar and are comparable with maritime background stations, such as Mace Head (Ireland). The diurnal cycle of ${ }^{222} \mathrm{Rn}$ follows the boundary layer height variations, with maximum values in the morning. Throughout the year but especially in summer and autumn, the $\mathrm{H}_{2}$ mixing ratio shows nighttime depletion, with the lowest values at 06:00 UTC, due to soil uptake and the low boundary layer height. Using a simple box approach and the Radon-Tracer-Method, the $\mathrm{H}_{2}$ deposition velocity is calculated for the catchment area of Trainou. We find a mean value for the $\mathrm{H}_{2}$ deposition velocity of $2.6 \pm 0.910^{-2} \mathrm{~cm} \mathrm{~s}^{-1}$. During wintertime, $\mathrm{H}_{2}$ and $\mathrm{CO}$ are sometimes strongly correlated leading to $\mathrm{H}_{2} / \mathrm{CO}$ ratio around 0.25 . This ratio is lower than the ratio from traffic emissions, thus highlighting the mixing of sources in this area.
\end{abstract}

\section{Introduction}

Since 1958, which saw the first long-term measurements of $\mathrm{CO}_{2}$ at Mauna Loa (Keeling et al., 1976), the global network of stations monitoring atmospheric trace gases has greatly expanded. North America and Western Europe are now covered by numerous stations; the rest of the globe is covered more sparsely. The objective of these sites is to describe the large-scale exchange of trace gases. To minimize the influence of local trace gas sources, marine or mountain stations such as Mace Head (a northern hemispheric background station on the west coast of Ireland) or Schauinsland (Germany) have traditionally been chosen (Schmidt et al., 2003; Grant et al., 2010a). However, due to the influence of topography on air mass transport and mixing, which results in large representation errors, measurements at mountain sites are difficult to reproduce using large-scale models. One solution for addressing this representation problem is to sample air at the top of tall towers located in plains. Throughout the European project CHIOTTO, a new station called Trainou

\footnotetext{
${ }^{*}$ Corresponding author.

e-mail: camille.yver@1sce.ipsl.fr

DOI: $10.1111 /$ j.1600-0889.2010.00520.x
}

Tower, located near the Orléans Forest was provided with instruments in 2007 (Messager, 2007) to analyse $\mathrm{CO}_{2}, \mathrm{CO}, \mathrm{CH}_{4}$, $\mathrm{N}_{2} \mathrm{O}$ and $\mathrm{SF}_{6}$. In 2008, within the framework of the European project EUROHYDROS, the analysis of $\mathrm{H}_{2}$ was added. With a mixing ratio of about $530 \mathrm{ppb}$, tropospheric molecular hydrogen is the second most abundant reduced trace gas in the troposphere after methane $\left(\mathrm{CH}_{4}\right)$ and it plays an important role in the $\mathrm{CH}_{4}$ budget as a product of $\mathrm{CH}_{4}$ oxidation and as a competitor in the reaction with the free hydroxyl radical $\mathrm{OH}$. Moreover, the development of $\mathrm{H}_{2}$ fuel cells in the future could lead to leakages during production and transport and therefore to an enhanced $\mathrm{H}_{2}$ mixing ratio in the troposphere. This effect would influence the $\mathrm{CH}_{4}$ mixing ratio in the troposphere and would affect the water vapour in the stratosphere (Tromp et al., 2003; Schultz et al., 2003; Jacobson, 2008). We briefly detail here the $\mathrm{H}_{2}$ budget as found in the literature (Novelli et al., 1999; Hauglustaine and Ehhalt, 2002; Sanderson et al., 2003; Xiao et al., 2007; Price et al., 2007; Ehhalt and Rohrer, 2009). The photolysis of $\mathrm{HCHO}$, a product in the oxidation chain of either methane or other volatile organic compounds (VOCs) accounts for about half of the global $\mathrm{H}_{2}$ source. Fossil fuel and biomass burning, two incomplete combustion sources have a similar share in the global $\mathrm{H}_{2}$ budget (20\% each). Minor $\mathrm{H}_{2}$ emissions 
originate from nitrogen fixation in plants on continents and in the oceans, completing the sources. These sources are balanced by the $\mathrm{H}_{2}$ oxidation through $\mathrm{OH}^{\cdot}$ and by the enzymatic $\mathrm{H}_{2}$ destruction in soils. $\mathrm{H}_{2}$ oxidation through $\mathrm{OH}$ accounts for only about $15-25 \%$ of the total $\mathrm{H}_{2}$ sink. $\mathrm{H}_{2}$ deposition is then the major sink in the $\mathrm{H}_{2}$ budget and it is responsible for the observed latitudinal gradient. This deposition, however, is poorly estimated due to uncertainties in the physical and chemical processes. The molecular hydrogen budget is thus rather uncertain, particularly in regard to soil uptake. Measuring $\mathrm{H}_{2}$ from a tall tower allows us access to vertical concentration gradients. In the last few years, numerous studies have been published that mainly focused on suburban sites (Steinbacher et al., 2007; Hammer and Levin, 2009; Aalto et al., 2009; Hammer et al., 2009; Yver et al., 2009; Grant et al., 2010b), whereas studies of rural continental sites are rare (Barnes et al., 2003; Grant et al., 2010a). As Trainou Tower is surrounded by fields and forests, we expect to observe a soil sink with less interference from local sources than at suburban sites like Gif-sur-Yvette (Yver et al., 2009). We can then estimate the soil sink using a simple box model or in combination with ${ }^{222} \mathrm{Rn}$ measurements.

In this paper, we present $\mathrm{H}_{2}, \mathrm{CO}$ and ${ }^{222} \mathrm{Rn}$ observations from the tall tower located at Trainou (Orléans Forest, 100 km southwest of Paris, France) from October 2008 until June 2010. In the first section, we describe the experimental set-up. The second section presents the $\mathrm{H}_{2}, \mathrm{CO}$ and ${ }^{222} \mathrm{Rn}$ observations. These time series provide information on seasonal and diurnal cycles and on vertical gradients. In the last sections, we focus on the temporal correlation of $\mathrm{H}_{2},{ }^{222} \mathrm{Rn}$ and $\mathrm{CO}$. The $\mathrm{H}_{2}$ soil uptake is estimated with two different methods in Section 3.2 and some pollution episodes are studied in Section 3.3.

\section{Experimental}

\subsection{Sampling location}

The Trainou sampling site $\left(47.96^{\circ} \mathrm{N}, 02.11^{\circ} \mathrm{E}, 131\right.$ masl, sampling height: 50,100 and $180 \mathrm{~m}$ ) belongs to the television transmission company TDF. Measurements on the tower are performed for the Laboratory for Climate and Environmental Sciences (LSCE) through the Atmospheric Network for Greenhouse Gas Monitoring (RAMCES). Trainou station is about $15 \mathrm{~km}$ northeast of the city of Orléans (350 000 inhabitants) and about $100 \mathrm{~km}$ south of Paris. The station is surrounded by five small villages ( $<2000$ habitants). Most of the nearby land is covered by the Orléans Forest $(22 \%)$ and by agricultural fields (50\%). Messager (2007) showed that the dominating winds are southwesterlies that transport relatively clean air followed by northeasterlies that are characterised by more polluted air masses. Since 2007, the station has been equipped with a $\mathrm{CO}_{2}$ analyser and a gas chromatograph that measures $\mathrm{CO}_{2}, \mathrm{CH}_{4}, \mathrm{~N}_{2} \mathrm{O}$ and $\mathrm{SF}_{6}$ (Messager, 2007). Semi-continuous measurements (4 analyses per hour) of atmospheric $\mathrm{CO}$ and $\mathrm{H}_{2}$ were added in
October 2008. ${ }^{222} \mathrm{Rn}$ analysis at $180 \mathrm{~m}$ began in May 2009 with two measurements per hour.

\section{2. $\mathrm{H}_{2}$ and $\mathrm{CO}$ measurement technique}

The $\mathrm{H}_{2}$ and $\mathrm{CO}$ measurement technique is detailed in Yver et al. (2009). Briefly, an automated gas chromatograph coupled with a reduction gas detector (RGD, Peak Laboratories, Inc., CA, USA) is used to analyse $\mathrm{H}_{2}$ and $\mathrm{CO}$. The air sampled from three different heights through 0.5 in. tubes (Dekabon type) and from cylinders is dried before injection. The precolumn (Unibeads $1 \mathrm{~S}$ mesh $60 / 80 ; 1 / 8$ in $\mathrm{OD} \times 16.5$ in) separates $\mathrm{H}_{2}$ and $\mathrm{CO}$ from other components and the analytical column (Molecular Sieve $5 \AA$ mesh $60 / 80 ; 1 / 8$ in OD $\times 80$ in) effectively separates $\mathrm{H}_{2}$ from CO. These two compounds are then reduced into mercury vapour on the mercury oxide bed. This vapour is analysed by UV absorption. One analysis takes about $5 \mathrm{~min}$ and on average, two air samples from each height are analysed per hour. The concentration of $\mathrm{H}_{2}$ is calculated using the MPI2009 scale (Jordan and Steinberg, 2010). For CO, we are using tanks calibrated in 2007 with the NOAA2004 scale (Novelli et al., 1991). The non-linearity of the RGD detector is corrected using a third degree polynomial fit. This correction and the calibration of the standard cylinder are evaluated every 3-6 months. The standard cylinder $\left(\mathrm{H}_{2}\right.$ and $\mathrm{CO}$ mixing ratios: 432.1 and $206.1 \mathrm{ppb}$, respectively) shows a good reproducibility of $0.5 \mathrm{ppb}$ for both $\mathrm{H}_{2}$ and $\mathrm{CO}$. The short-term reproducibility (i.e. the standard deviation of $24 \mathrm{hr}$ measurements) of the control cylinder $\left(\mathrm{H}_{2}\right.$ and $\mathrm{CO}$ mixing ratios: 870 and $50 \mathrm{ppb}$, respectively) is below $2 \mathrm{ppb}$ for $\mathrm{H}_{2}$ and $0.5 \mathrm{ppb}$ for $\mathrm{CO}$. The long-term reproducibility calculated from the regular injections of the control cylinder over the whole measurement period reaches $7.5 \mathrm{ppb}$ (this elevated value is due to a drift in $\mathrm{H}_{2}$ concentrations in the control cylinder during the first year of measurements) for $\mathrm{H}_{2}$ and $0.8 \mathrm{ppb}$ for $\mathrm{CO}$. The comparison between cylinders analysed at Trainou and Gif-surYvette shows good agreement with a mean difference below 1 and $2 \mathrm{ppb}$ for $\mathrm{H}_{2}$ and $\mathrm{CO}$, respectively. Greater variability is shown by a comparison between the flasks sampled at $180 \mathrm{~m}$, analysed at the central laboratory of Gif-sur-Yvette, and in situ measurements of the $180 \mathrm{~m}$ inlet line performed in a $2 \mathrm{~h}$ time span around the flask sampling. Indeed, the mean offset between flask and ambient air measurements is $4 \pm 5 \mathrm{ppb}$ for $\mathrm{H}_{2}$ and $2 \pm 3 \mathrm{ppb}$ for $\mathrm{CO}$. This greater difference and the high-associated standard deviation can be explained by the large variability of the ambient air mixing ratios.

\subsection{Radon-222 measurement technique}

Radon-222 $\left({ }^{222} \mathrm{Rn}\right)$ is a natural radioactive gas in the uranium238 decay series. ${ }^{222} \mathrm{Rn}$ is emitted by soils and is therefore more abundant above continental surfaces than over the oceans. As a noble gas, ${ }^{222} \mathrm{Rn}$ is chemically inert and its mobility depends only on physical processes (diffusion, adsorption, advection). 
The exhalation rate of ${ }^{222} \mathrm{Rn}$ changes with soil type and meteorological conditions such as atmospheric pressure, soil water content or precipitation (Schery et al., 1984). Its half-life of 3.82 days makes ${ }^{222} \mathrm{Rn}$ a good tracer for regional atmospheric circulation studies. Since May 2009, the ${ }^{222} \mathrm{Rn}$ concentration at the 180-m height of Trainou Tower has been determined using a two-filter radon detector. In the two-filter method (Whittlestone and Zahorowski, 1998; Zahorowski et al., 2004), ambient air is continuously pumped through a $400-\mathrm{L}$ thoron $\left({ }^{220} \mathrm{Rn}\right)$ delay volume (in our case, the $180 \mathrm{~m}$ sampling tube with a diameter of $65 \mathrm{~mm}$ plays the role of this delay volume) and through the first filter to the analysis chamber. During this first step, ${ }^{220} \mathrm{Rn}$ disintegrates because the residence time is 10 times higher than its half-life and the filter retains ${ }^{222} \mathrm{Rn}$ daughters attached to aerosols allowing only ${ }^{222} \mathrm{Rn}$ into the analysis chamber. In this chamber, new ${ }^{222} \mathrm{Rn}$ daughters are produced and collected on the second filter. The $\alpha$-decay of these daughter elements is then counted. The instrument is regularly calibrated with a known quantity of ${ }^{222} \mathrm{Rn}$ emitted by a ${ }^{226} \mathrm{Ra}$ source. Two measurements per hour are performed.

\section{Results and discussion}

\subsection{Diurnal and seasonal cycles}

Figure 1 presents the time series at each sampling height for 1 week in January 2010 and 1 week in August 2009. The $\mathrm{H}_{2}$ and $\mathrm{CO}$ mixing ratios are far greater in winter than in summer with $\mathrm{CO}$ varying between 80 and $500 \mathrm{ppb}$ and $\mathrm{H}_{2}$ between 490 and $610 \mathrm{ppb}$ (note that the scales of the $y$-axes are different for the two panels). In summer, the variations range from 40 to $150 \mathrm{ppb}$ and from 480 to $560 \mathrm{ppb}$ for $\mathrm{CO}$ and $\mathrm{H}_{2}$, respectively. The 2 weeks shown in Fig. 1 are typical of specific events: in winter, episodes of strong pollution with a high correlation of $\mathrm{H}_{2}$ and $\mathrm{CO}$ during a few hours to a few days are observed; ${ }^{222} \mathrm{Rn}$ is also correlated with the two other gases sampled at $180 \mathrm{~m}$ but to a lesser extent as its variations are solely due to the transport of polluted air masses and is not influenced by local pollution sources. In summer, the dominating influence of the $\mathrm{H}_{2}$ soil sink leads to the anticorrelation of $\mathrm{H}_{2}$ and ${ }^{222} \mathrm{Rn}$ during the night with the strongest $\mathrm{H}_{2}$ decrease observed at the 50-m height. During the same period, $\mathrm{CO}$ is partly correlated with ${ }^{222} \mathrm{Rn}$. As shown in Fig. 1, the decrease in the $\mathrm{H}_{2}$ mixing ratio at $50 \mathrm{~m}$ preceeds the increase in ${ }^{222} \mathrm{Rn}$ concentration at $180 \mathrm{~m}$ due to the greater influence of the soil uptake at the lower level.

The left panel of Fig. 2 presents the complete time series for $\mathrm{H}_{2}, \mathrm{CO}$ and ${ }^{222} \mathrm{Rn}$ from October 2008 to September 2010. Large variations in the mixing ratios of the three gases combined with the seasonal cycles are observed. The CO mixing ratios vary between 100 and $600 \mathrm{ppb}$, with the maximum values mainly observed during wintertime. The $\mathrm{H}_{2}$ mixing ratios fluctuate between 400 and $700 \mathrm{ppb}$, with maximum values dispersed over the entire series. The ${ }^{222} \mathrm{Rn}$ concentration varies between
0 and $30 \mathrm{~Bq} \mathrm{~m}^{-3}$. The monthly mean baseline, calculated using the afternoon values (between 14:00 and 18:00 UTC) when the boundary layer is well mixed, is plotted with crosses. For $\mathrm{H}_{2}$, we observe nightly values that are lower than the baseline due to soil uptake.

On the right panel, the baseline curves for Trainou Tower as defined previously, are plotted separately to highlight the seasonal cycles of the three gases. $\mathrm{CO}$ reaches its maximum in winter and its minimum in summer with a seasonal amplitude of 75 ppb peak-to-peak. The $\mathrm{CO}$ anthropogenic emissions and the boundary layer height variations lead to the winter maximum in $\mathrm{CO}$ mixing ratios whereas the $\mathrm{OH}$ sink, which is at its maximum in summer, causes the minimum. The $\mathrm{H}_{2}$ presents its maximum in spring and its minimum in autumn with a seasonal amplitude of 45 ppb peak-to-peak. This pattern is mainly explained by the seasonality of the soil sink even if, as for the other trace gases, the boundary-layer dynamics lead to enhanced concentrations during winter and lower concentrations during summer. In the northern hemisphere, the soil sink is strongest at the end of summer, being driven by the enzymatic activity, which is enhanced by dry and warm conditions, and it has its minimum in early spring (Ehhalt and Rohrer, 2009). ${ }^{222} \mathrm{Rn}$ shows a small seasonal pattern with a maximum in autumn and a minimum in spring. The seasonal variations of the boundary layer height (higher in summer and lower in winter) and of the ${ }^{222} \mathrm{Rn}$ flux can explain this seasonality. As the baseline values are selected when the boundary layer is well mixed, we expect no significant difference between the three different heights and we expect a good agreement with the clean marine air at the same latitude. To make this comparison, the background fit from the flasks sampled at Mace Head on the west coast of Ireland is plotted as a black dotted line. The grey-filled circles plot the baseline computed for Gif-sur-Yvette (20 km south of Paris; Yver et al., 2009) with the same method used for Trainou. For $\mathrm{H}_{2}$ and $\mathrm{CO}$, the three different heights agree well with each other and with the two other series of Gif-sur-Yvette and Mace Head. However, we can see that the Mace Head data for $\mathrm{H}_{2}$ and $\mathrm{CO}$ are delayed from Gif and Trainou by about 1 month. This delay can be explained by the sources and sinks being located on the continent. For ${ }^{222} \mathrm{Rn}$, the concentrations at Trainou are similar to these of Gif-sur-Yvette. At Mace Head, the ${ }^{222} \mathrm{Rn}$ concentrations are approximately two times lower, due to the oceanic influence.

Figure 3 shows the mean diurnal cycles for $\mathrm{H}_{2}$ and $\mathrm{CO}$ for the three different heights and for ${ }^{222} \mathrm{Rn}$ at $180 \mathrm{~m}$ and the boundary layer height modelled at the European Center for Medium range Weather Forecasting (ECMWF) for Trainou Tower. The annual, winter and summer mean diurnal cycles are presented from top to bottom. The boundary layer height is always lower during the night and higher during the day, with the maximum between 12:00 and 15:00 UTC. In summer, the maximum values are higher (up to $1500 \mathrm{~m}$ ) than in winter (around $700 \mathrm{~m}$ ). The mean minimum value is $250 \mathrm{~m}$. The number of nights when the 

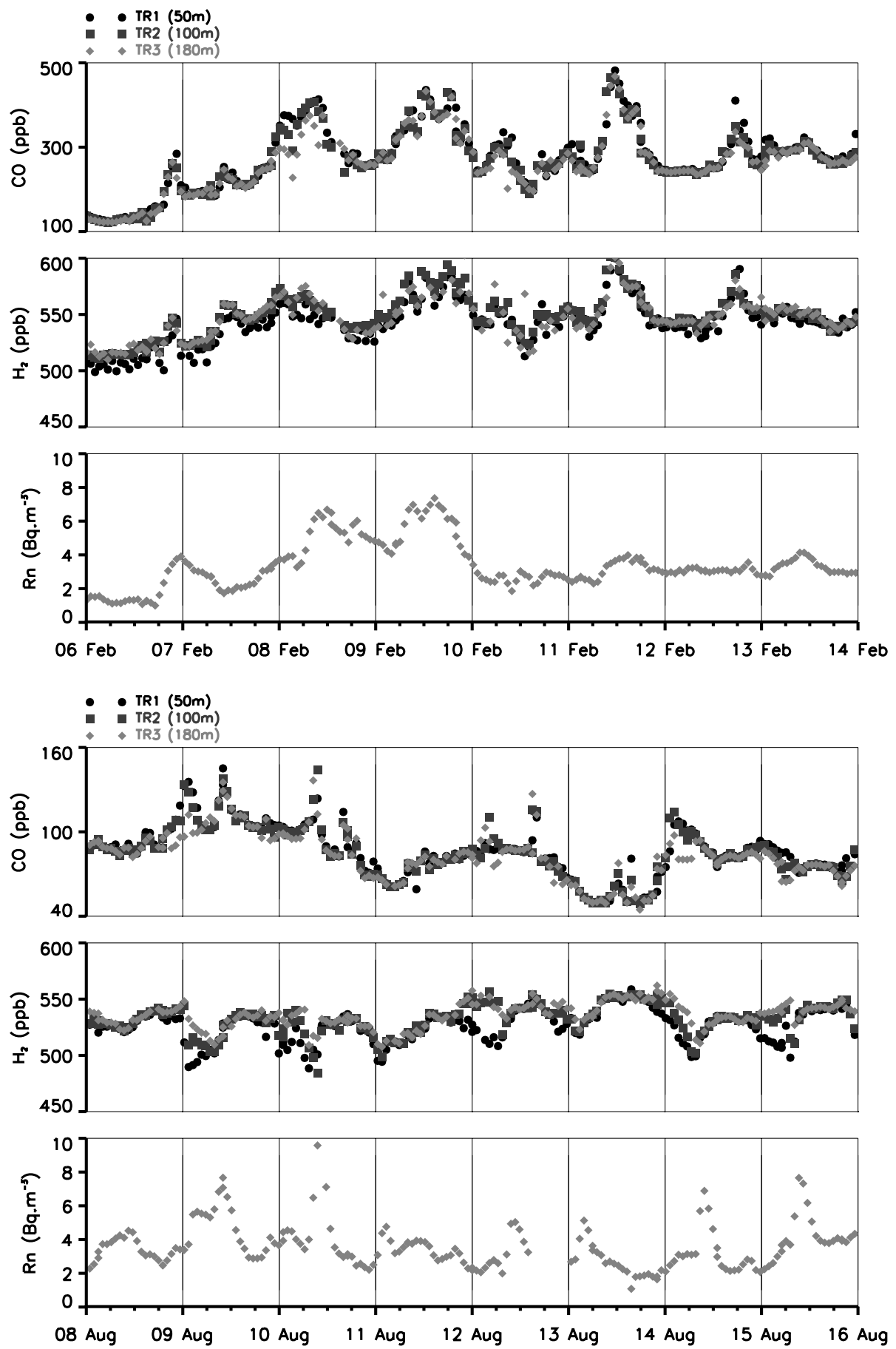

Fig. 1. Two weeks of $\mathrm{CO}, \mathrm{H}_{2}$ and ${ }^{222} \mathrm{Rn}$. Each height is plotted with a different symbol: $50 \mathrm{~m}$ with full circles, $100 \mathrm{~m}$ with full squares and $180 \mathrm{~m}$ with full diamonds. Upper panel: February 2010. Lower panel: August 2009. The scale of the $y$-axis differs from one panel to the other. Please note that the time scale is in UTC time.

boundary layer height is below $180 \mathrm{~m}$ account for $50 \%$ of all the nights.

As expected from Fig. 2 and from the daily boundary layer dynamics, during the afternoon in all seasons, there is no significant difference between the three sampling heights for $\mathrm{H}_{2}$ and
$\mathrm{CO}$. For $\mathrm{CO}$, there is almost no difference in summer between different sampling heights, though we observe a very low level of concentrations, around $110 \mathrm{ppb}$, whereas in winter there is a strong vertical gradient, except in the afternoon, combined with high concentrations $(\approx 200 \mathrm{ppb})$. The lowest mixing ratio are 


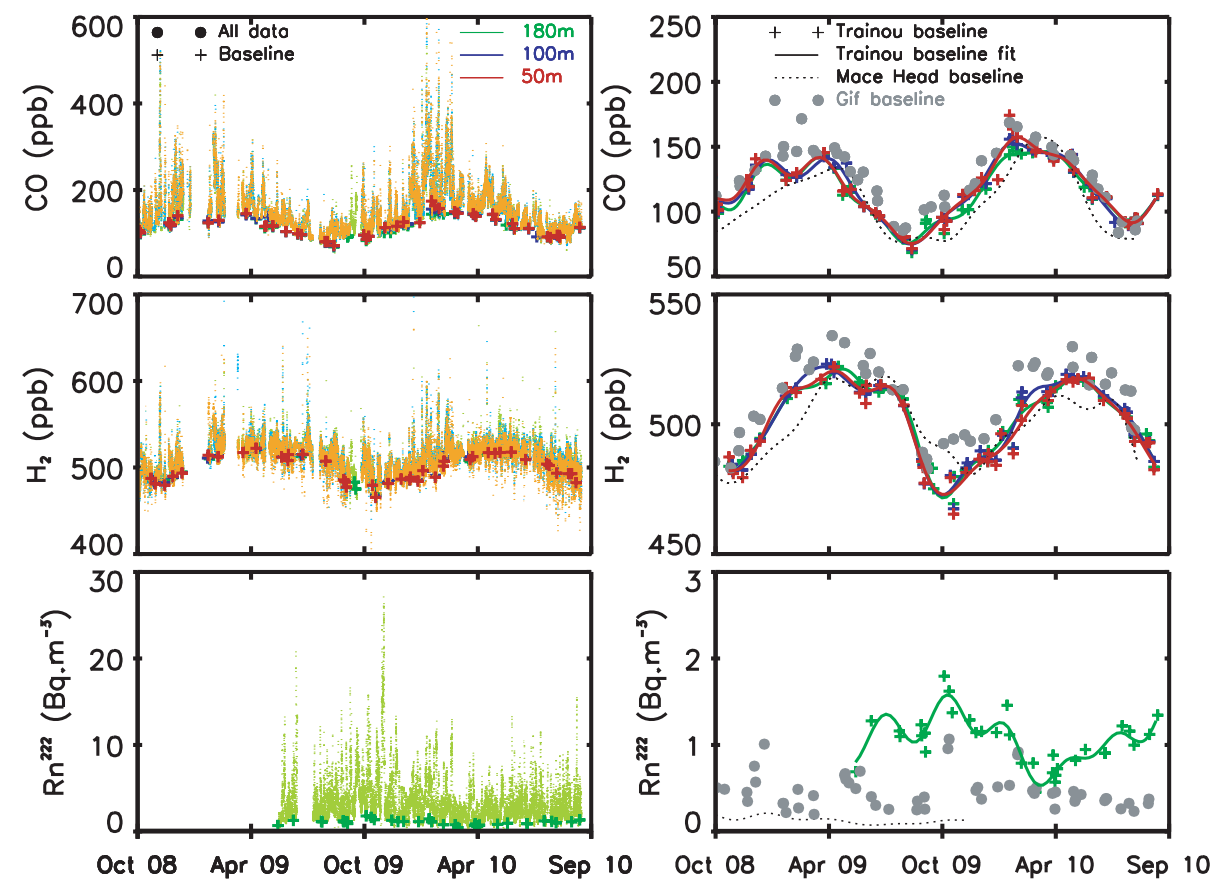

Fig. 2. Seasonal variations of $\mathrm{H}_{2}, \mathrm{CO}$ and ${ }^{222} \mathrm{Rn}$. The different colours plot the three sampling levels (dark and light green: $50 \mathrm{~m}$, dark and light blue: $100 \mathrm{~m}$, red and orange: $180 \mathrm{~m}$ ). Left panel: The hourly mean data are plotted with dots (light colours), the baseline values from Trainou with crosses (dark colours); Right panel: the monthly mean baseline values from Trainou are plotted with coloured crosses; the monthly mean baseline curve from Gif-sur-Yvette with grey full circles and the fitted flask measurements from Mace Head as black dotted line. The scale of the $y$-axis is zoomed from left to right.

measured at $180 \mathrm{~m}$ where the air is less influenced by the local emissions. The gradient between 50 and $180 \mathrm{~m}$ reaches up to $40 \mathrm{ppb}$ in winter. For $\mathrm{H}_{2}$, in winter, there is almost no difference between the three heights. In summer, due to the influence of the soil sink at the lower level, the gradient can reach up to $20 \mathrm{ppb}$. The mean concentration stays around $540 \mathrm{ppb}$ throughout the year. With the soil sink predominating during nighttime, when the boundary layer is low and the emissions reduced, the lowest mixing ratio are encountered at $50 \mathrm{~m}$. The 100- and 180-m levels do not differ significantly and in summer are up to $20 \mathrm{ppb}$ higher than the 50-m level. Contrary to the suburban site of Gif-surYvette (Yver et al., 2009), we do not observe a correlation of $\mathrm{H}_{2}$ or $\mathrm{CO}$ with traffic peaks. The proximity of the city of Orléans do not seem to significantly influence the measurements. Either the site receives no polluted air masses or, more likely, with the nearby highways (more than 25000 vehicles per day DREC, 2007), there is a relatively constant truck and car circulation which leads to a stable daily level of fossil fuel emissions. ${ }^{222} \mathrm{Rn}$ presents a mean concentration of $\approx 3 \mathrm{~Bq} \mathrm{~m}^{-3}$. The greatest variations are seen in summer whereas in winter, there is almost none. This observation can be explained by the boundary-layer dynamics which encounter more variability in summer than in winter. The maximum is reached at around 10:00 UTC and the minimum is reached in the afternoon between 16:00 and 18:00 UTC. As the ${ }^{222} \mathrm{Rn}$ emission flux is rather constant in time
(Schery et al., 1984), the daily variations of the ${ }^{222} \mathrm{Rn}$ concentration are mostly caused by the daily boundary layer dynamics. In the afternoon, when the boundary layer height is greater and the boundary layer well mixed, the ${ }^{222} \mathrm{Rn}$ is diluted and the concentrations reach their minimum. During night, the boundary layer is lower and the concentrations increase until the morning when the stable boundary layer breaks up.

We have also investigated the variations of the vertical gradient during the day. The diurnal variations are computed using the gradient between 50 and $180 \mathrm{~m}$ calculated at each sampling time. The results are shown in Fig. 4. On the left panel, we have plotted the diurnal variations of the yearly mean gradient for $\mathrm{CO}$ and $\mathrm{H}_{2}$. For $\mathrm{CO}$, the vertical gradient variations follow the evolution of the boundary layer height. During the day, the boundary layer height grows to reach its maximum during the afternoon. The air masses are then well mixed and the vertical gradient approaches zero between 50 and $180 \mathrm{~m}$. During the night, the $180-\mathrm{m}$ can be higher than the boundary layer thus encountering air masses from the free troposphere with a lower $\mathrm{CO}$ mixing ratio. In contrast, at the 50-m level, the measurements remain influenced by the boundary layer emissions which are also concentrated in the low boundary layer. Here, we can observe a negative vertical gradient up to $-20 \mathrm{ppb}$. For $\mathrm{H}_{2}$, this analysis is different because of the soil sink effect. As for CO, we measure a weak vertical gradient during the afternoon with 

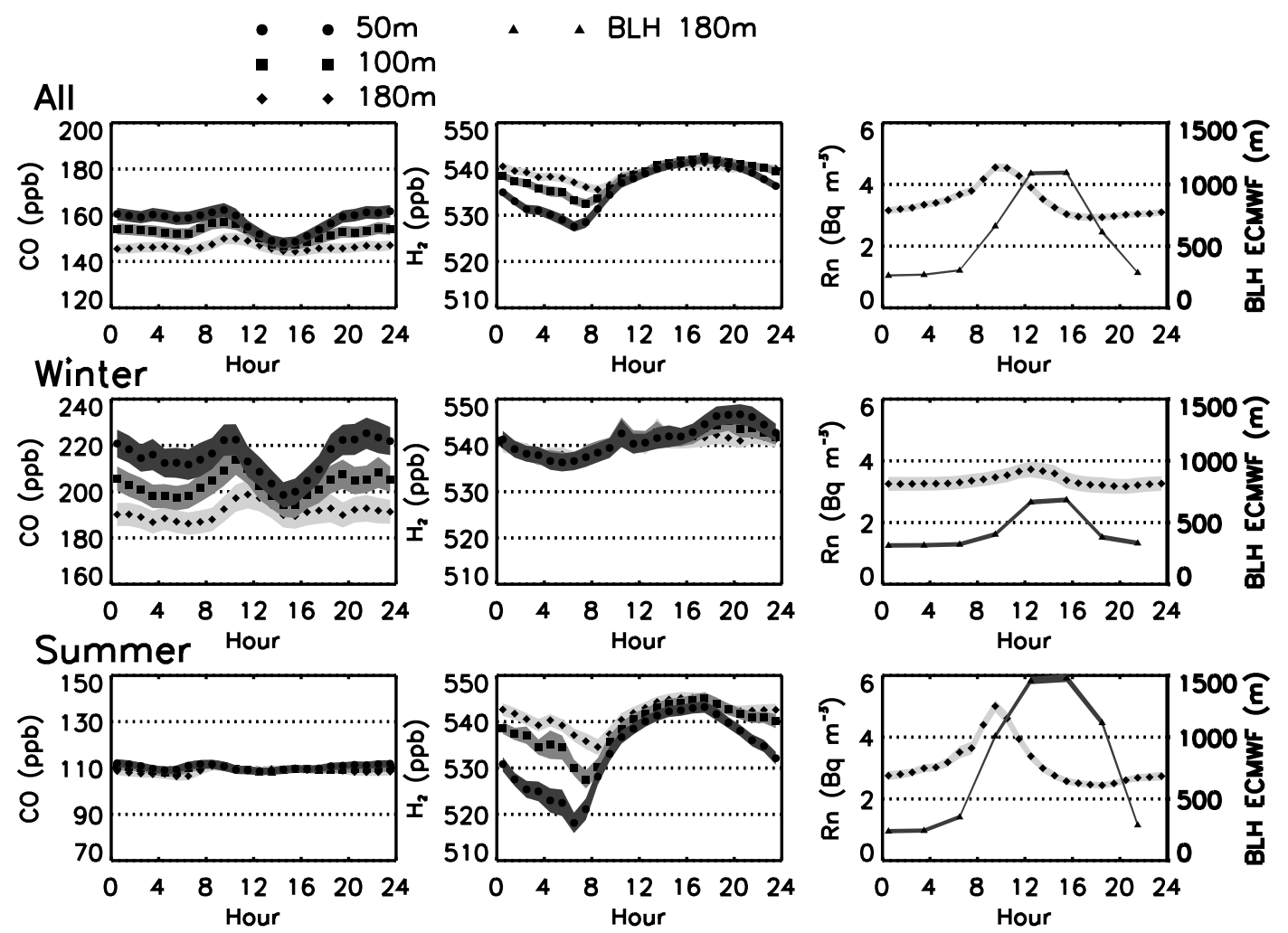

Fig. 3. Mean diurnal cycles (UTC) of CO, $\mathrm{H}_{2},{ }^{222} \mathrm{Rn}$ for the three different levels (full circles: $50 \mathrm{~m}$, full squares: $100 \mathrm{~m}$, full diamonds: $180 \mathrm{~m}$ ). On the same panel as the ${ }^{222} \mathrm{Rn}$ is plotted the boundary layer height (BLH) with full triangles. Top panel: yearly mean, middle panel: winter mean and bottom panel: summer mean. For CO, the scale of $y$-axis differs for each plot but we kept the same interval ( $80 \mathrm{ppb})$.
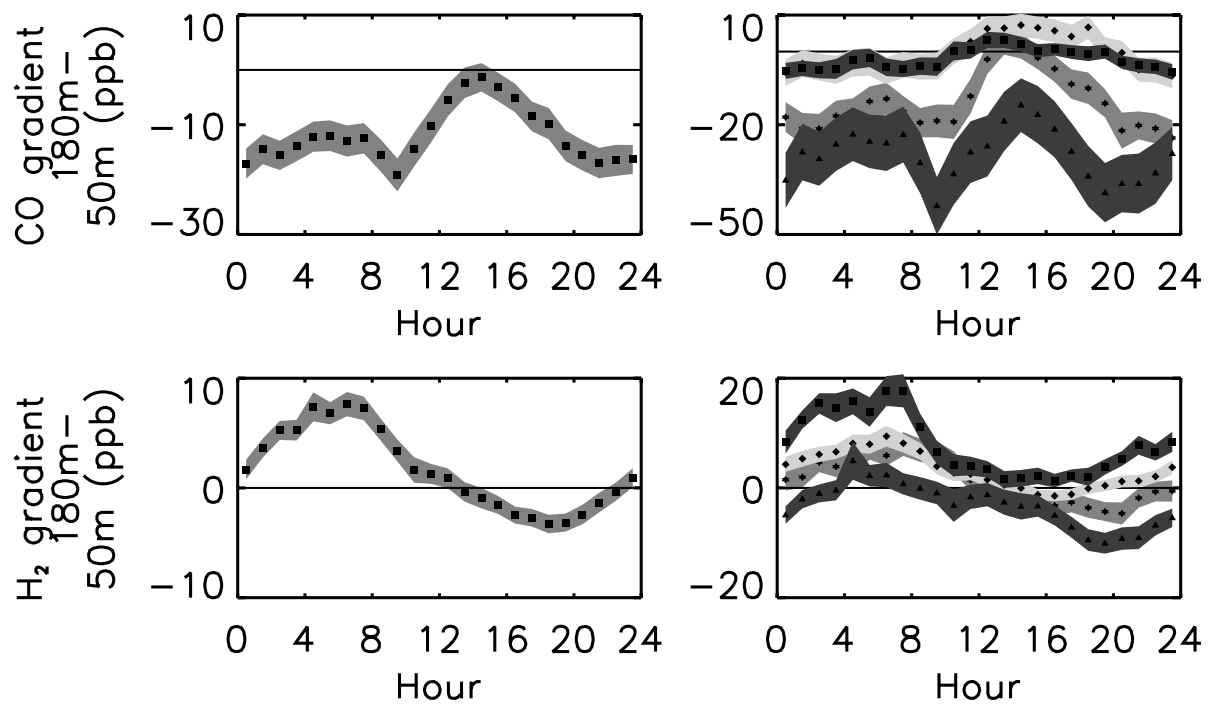

- All data

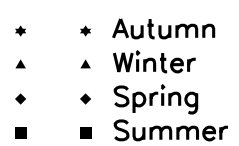

Fig. 4. Diurnal cycle (UTC) of the vertical gradient between the 50 and 180-m sampling heights for $\mathrm{CO}$ and $\mathrm{H}_{2}$. Left panel: Yearly averaged data. Right panel: Seasonally averaged data (stars: autumn, triangles: winter, circles: spring and squares: summer). The scale of $y$-axis differs from one plot to another. 
a well-mixed layer, but during the night, the lowest mixing ratio are found near the ground. The resulting positive vertical yearly mean gradient reaches up to $8 \mathrm{ppb}$. On the right panel of the graph, the vertical gradient is plotted for each season. In winter, with a higher level of anthropogenic emissions, the negative vertical gradient for $\mathrm{CO}$ can reach up to $-40 \mathrm{ppb}$ during the night. For $\mathrm{H}_{2}$, the diurnal variation of the vertical gradient seen on the left panel is mostly induced by the summer variation (maximum $20 \mathrm{ppb}$ ) when the soil sink is more active. During the rest of the year, the smaller decrease due to the weaker soil sink leads to a small positive vertical gradient or even a negative gradient. From these observations, we expect to measure the strongest soil deposition velocity in summer and the lowest in winter. To estimate this soil sink, we have used the two methods described and discussed in the next section.

\section{2. $\mathrm{H}_{2}$ deposition velocity}

Trainou Tower is surrounded by forests and arable land. We can then expect to observe the soil-uptake effect, which causes a strong decrease of $\mathrm{H}_{2}$ mixing ratios, more easily than at Gif-surYvette where the measurements are influenced by local traffic sources. We calculate the $\mathrm{H}_{2}$ deposition velocity using two different methods. The first method is based on a simple approach using a box model. The second method is the Radon-TracerMethod, which has been widely used to estimate trace gas fluxes (Levin et al., 1999; Biraud et al., 2000; Schmidt et al., 2001; Messager, 2007; Hammer and Levin, 2009; Yver et al., 2009).

In the first case, we use the vertical gradient of mixing ratios between 50 and $180 \mathrm{~m}$. We assume that there is no change in the vertical gradient due to mixing, but that the change in mixing ratios is entirely caused by the soil sink. During such conditions, there is no mixing of air between the two levels which leads to a stable $180-\mathrm{m}$ mixing ratio and a decreasing 50-m mixing ratio. Moreover, we suppose that the $\mathrm{H}_{2}$ sink flux remains constant during the event. We can then write

$C_{180}-C_{50 \mathrm{~m}}=-j_{\mathrm{H}_{2}} \times \frac{\Delta t}{H}$

with $C_{180}$ being the mixing ratio at $180 \mathrm{~m}, C_{50 \mathrm{~m}}$ the mixing ratio at $50 \mathrm{~m}, j_{\mathrm{H}_{2}}$ the $\mathrm{H}_{2}$ deposition flux, $t$ the period and $H$ the height of the box (in our case, $180-50=130 \mathrm{~m}$ ). At night, there are no more photochemical sources and sinks and there are fewer anthropogenic activities. Therefore, one can assume that the soil sink is the only term that is measured. Between 23.00 and 04:00 UTC, the boundary layer is stable (Fig. 3). We then select the events with a decreasing $C_{50 \mathrm{~m}}$ and a stable $C_{180}$ between 23:00 and 04:00 UTC. To be selected as stable, the variation of the mixing ratio at $180 \mathrm{~m}$ during this period should stay below $10 \mathrm{ppb}$ (i.e. $\pm 2 \%$ of the mean concentration). Moreover, we estimate that the decrease of the mixing ratio has to be greater than $15 \mathrm{ppb}$ to be significant for a dominating soil sink and not the result of a mix between sink and sources.
The second method is the Radon-Tracer-Method as described in detail for the Gif-sur-Yvette station in Yver et al. (2009). Gas fluxes (deposition for $\mathrm{H}_{2}$ and exhalation for ${ }^{222} \mathrm{Rn}$ ) can be estimated using a simple one-dimensional approach; assuming that the gas is released from the atmosphere at a constant rate $\mathrm{J}$ in a well-mixed layer of height $\mathrm{H}$, we can write the temporal variation of its concentration (with an additional radioactive decay term for ${ }^{222} \mathrm{Rn}$ ). If we combine the two equations, we eliminate the boundary layer height

$J_{\mathrm{H}_{2}}=J_{\mathrm{Rn}} \frac{\Delta C_{\mathrm{H}_{2}}}{\Delta C_{\mathrm{Rn}}}\left(1-\frac{\lambda_{\mathrm{Rn}} C_{\mathrm{Rn}}}{\frac{\Delta C_{\mathrm{Rn}}}{\Delta t}}\right)$.

$J_{\mathrm{Rn}}$ is the mean ${ }^{222} \mathrm{Rn}$ emission rate of the region of influence, $\frac{\Delta C_{\mathrm{H}_{2}}}{\Delta C_{\mathrm{Rn}}}$ is the slope of the linear regression of half-hourly observations between $\mathrm{H}_{2}$ and ${ }^{222} \mathrm{Rn}$ and $\left(1-\frac{\lambda_{\mathrm{Rn}} C_{\mathrm{Rn}}}{\frac{\Delta C_{\mathrm{Rn}}}{\Delta t}}\right)$ is the factor used to correct for ${ }^{222} \mathrm{Rn}$ radioactive decay. Schmidt et al. (2001) showed that during a typical nighttime inversion situation lasting 8-12 h, the change in radon activity as a result of radioactive decay, offset by fresh emission from soil, was only $3-4 \%$. On the basis of this work, we used a correction factor of 0.965 . In this approach, the gas fluxes are considered collocated spatially and temporally, with no mixing of air from the free troposphere. The boundary layer height and the gas fluxes are assumed to remain constant during each event. We apply our methods between 23:00 and 04:00 UTC, for the same reasons that we outlined for the box model, using a weighted least-squares algorithm. The selection of events for the Radon-Tracer-Method is nearly the same as for Gif-sur-Yvette:

(1) the correlation between $\mathrm{H}_{2}$ and ${ }^{222} \mathrm{Rn}$ must be negative between 23:00 and 04:00 UTC.

(2) the ${ }^{222} \mathrm{Rn}$ concentration increase has to be over after 08:00 UTC to select only night-time inversion events.

(3) the coefficient of determination $\left(R^{2}\right)$ should be greater than 0.6 .

(4) the error on the $\mathrm{H}_{2} / \mathrm{Rn}$ slope must be less than $50 \%$ (this criterium is chosen so loose to eliminate outliers and not to select events).

These criteria are chosen to obtain a balance between a high correlation and a significant number of selected events. There are no measurements of the ${ }^{222} \mathrm{Rn}$ flux for the surroundings of Trainou to our knowledge. To estimate this ${ }^{222} \mathrm{Rn}$ flux, we therefore use two methods. First, with the soil texture map of Zobler (1986) and the mean ${ }^{222} \mathrm{Rn}$ fluxes estimated by Jutzi (2001), we find a mean value of $53.4 \mathrm{~Bq} \mathrm{~m}^{-2} \mathrm{~h}^{-1}$. Secondly, we infer a flux with the radon map provided by Szegvary et al. (2008). The mean flux reaches $46.08 \mathrm{~Bq} \mathrm{~m}^{-2} \mathrm{~h}^{-1}$. We then choose the mean value of $50 \mathrm{~Bq} \mathrm{~m}^{-2} \mathrm{~h}^{-1}$. Due to the lack of data, we use the same seasonal amplitude of $25 \%$ more in summer and $25 \%$ less in winter as for Gif-sur-Yvette and Heidelberg (Hammer and Levin, 2009; Yver et al., 2009). Finally, the deposition velocity 

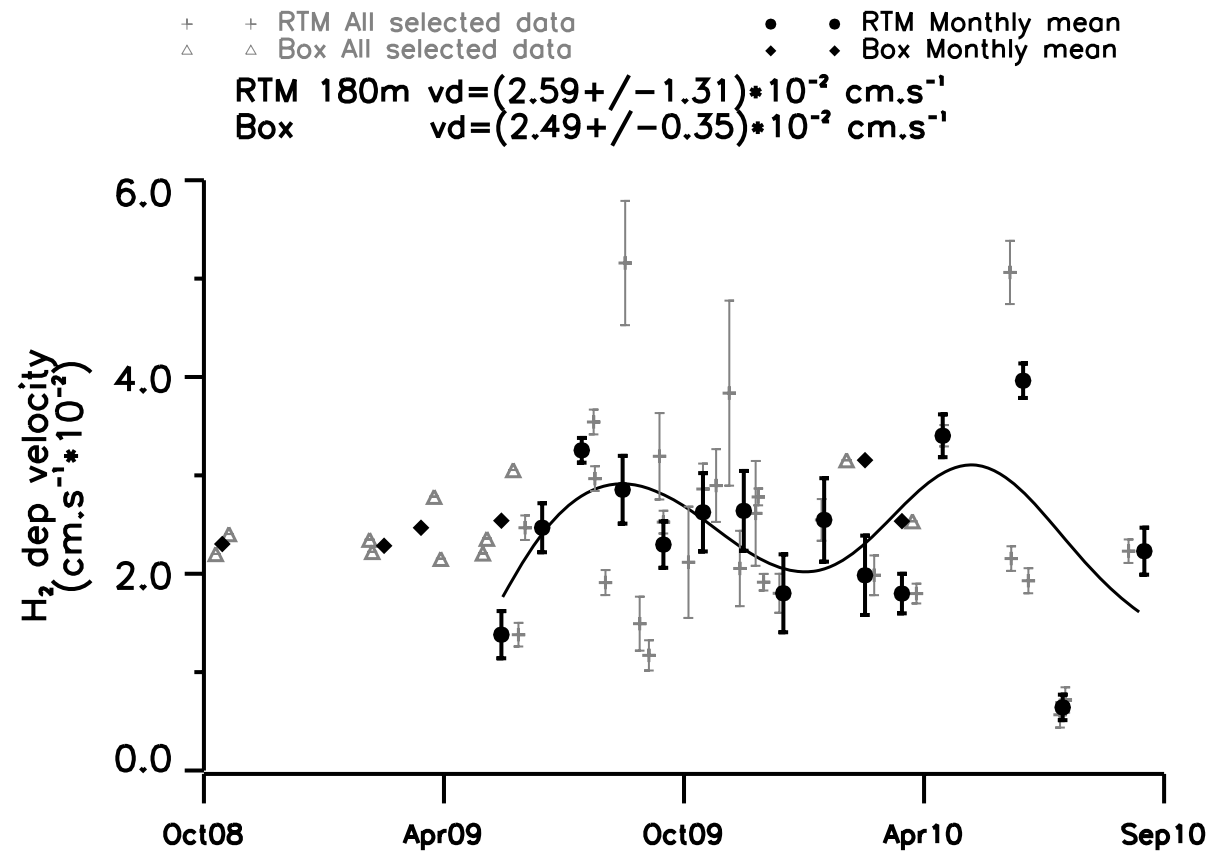

Fig. 5. Deposition velocity of $\mathrm{H}_{2}$ calculated with the Radon-Tracer-Method (RTM, plotted with full circles for the monthly mean and crosses for each event) and with the simple box model (box, plotted with full diamonds for the monthly mean and triangles for each event). The error bars represent the errors computed by the weighted least-squares algorithm.

is inferred from the flux by

$v_{\mathrm{d}}=\frac{J_{\mathrm{H}_{2}}}{C_{\mathrm{H}_{2}}}$

with $C_{\mathrm{H}_{2}}$ the mean $\mathrm{H}_{2}$ concentration of the month. The results for the two methods are presented in Fig. 5. With the box model (blue symbols), we select only 16 events (2\%) out of 900 nights. We then calculate a mean flux of $4.2 \pm 0.5$ $10^{-5} \mathrm{~g} \mathrm{~m}^{-2} \mathrm{~h}^{-1}$, corresponding to a mean deposition velocity of $2.5 \pm 0.310^{-2} \mathrm{~cm} \mathrm{~s}^{-1}$. No seasonal cycle is apparent and most of the events are selected during spring. The number of events and their repartition can be partly due to the seasonal variations of the boundary layer. Indeed, to apply our model, we need a nearly constant mixing ratio at $180 \mathrm{~m}$ that is to say a stable boundary layer. In summer, with the temperature gradient, there is generally more advection. We also observe a decrease in the 180-m level, which is what we used for the Radon-TracerMethod. In winter, as stated previously, the soil sink is weak and we tend to reject events with a mixing ratio decrease less than $15 \mathrm{ppb}$. Moreover, the decrease in the $\mathrm{H}_{2}$ mixing ratio can be balanced by emissions leading to a smaller gradient and a smaller flux.

As the ${ }^{222} \mathrm{Rn}$ gas measurements only began in May 2009, we have 16 months of hydrogen deposition velocities calculated with the Radon-Tracer-Method. Applying the criterion of a negative slope between $\mathrm{H}_{2}$ and ${ }^{222} \mathrm{Rn}, 50 \%$ of the available 350 nights are initially selected. Another $30 \%$ are rejected by choosing a coefficient of determination greater than 0.6 and the events with the radon increase stopped after 08:00. Finally, we keep $7 \%$ of the nights after the 3 -sigma iterative filter. The mean value of the flux reaches $-4.3 \times 10^{-5} \pm 2.1 \times 10^{-5} \mathrm{~g} \mathrm{~m}^{-2} \mathrm{~h}^{-1}$ and the mean deposition velocity is $2.6 \pm 1.3 \times 10^{-2} \mathrm{~cm} \mathrm{~s}^{-1}$. As expected from the seasonality of the sink, we observe a seasonal cycle with a maximum in September and a minimum in March. The amplitude of the seasonal cycle reaches $40 \%$ of the annual mean.

We calculate the deposition fluxes during the night to minimize the influence of the other terms. Nevertheless, anthropogenic emissions from the city of Orléans or from the highways are still expected. We estimate these emissions by scaling the nocturnal $\mathrm{CO}$ emissions from Thiruchittampalam and Köble (2008) (provided with a 0.5 degree resolution) by using a ratio of $0.034 \mathrm{~g}\left(\mathrm{H}_{2}\right) / \mathrm{g}(\mathrm{CO})$ (Yver et al., 2009). The $\mathrm{CO}$ emissions around Trainou between 23:00 and 04:00 UTC are estimated to be 6.4 $\times 10^{-6} \mathrm{~g} \mathrm{~m}^{-2} \mathrm{~h}^{-1}$, which lead to $\mathrm{H}_{2}$ anthropogenic nocturnal emissions of $2.2 \times 10^{-7} \mathrm{~g} \mathrm{~m}^{-2} \mathrm{~h}^{-1}$. This emission flux has to be compared to the $\mathrm{H}_{2}$ deposition flux of $-4.3 \times 10^{-5} \mathrm{~g} \mathrm{~m}^{-2} \mathrm{~h}^{-1}$. The nocturnal anthropogenic emissions represent here only $0.5 \%$ of the inferred deposition flux and are therefore, not taken into account. The greatest uncertainties come from the estimation of the ${ }^{222} \mathrm{Rn}$ flux which can be estimated as $\approx 25 \%$. The error on the slope reaches $11 \%$ leading to an overall uncertainty of $\approx 30 \%$.

The estimation of soil uptake for the two methods is based on the decrease on the $\mathrm{H}_{2}$ mixing ratios. During winter and spring, when the deposition is weak, the methods do not select any 
Table 1. Hydrogen deposition velocity in suburban and rural areas.

\begin{tabular}{|c|c|c|c|c|c|}
\hline \multirow[b]{2}{*}{ Reference } & \multicolumn{2}{|c|}{ Deposition velocity } & \multirow[b]{2}{*}{ Seasonal cycle amplitude } & \multirow[b]{2}{*}{ Location } & \multirow[b]{2}{*}{ Method } \\
\hline & $\begin{array}{l}\text { Range } \\
\left(10^{-2} \mathrm{~cm} \mathrm{~s}^{-1}\right)\end{array}$ & $\begin{array}{l}\text { Mean } \\
\left(10^{-2} \mathrm{~cm} \mathrm{~s}^{-1}\right)\end{array}$ & & & \\
\hline Yonemura et al. (2000) & $0-9$ & 4.3 & - & Field (Tsukuba, Japan) & Chamber \\
\hline Yonemura et al. (2000) & $5-8$ & 6.3 & - & Forest (Tsukuba, Japan) & Chamber \\
\hline Steinbacher et al. (2007) & $0.5-1$ & - & - & Suburb (Dübendorf,Switzerland) & Boundary layer \\
\hline Schmitt et al. (2009) & $1-8$ & - & - & Field (Heidelberg, Germany) & Chamber \\
\hline Hammer and Levin (2009) & $1-8$ & 3.0 & $25 \%$ & Suburb (Heidelberg, Germany) & Radon tracer \\
\hline Yver et al. (2009) & $0.6-6.0$ & 2.4 & $30-50 \%$ & Suburb (Gif-sur-Yvette, France) & Radon Tracer \\
\hline Grant et al. (2010b) & $0.9-5.7$ & 2.2 & - & Suburb (Bristol, UK) & Boundary layer \\
\hline This study & $0.5-5$ & 2.6 & $20 \%$ & Forest and fields (Trainou, France) & Radon Tracer \\
\hline This study & $2-3.5$ & 2.5 & - & Forest and fields (Trainou, France) & Box model \\
\hline
\end{tabular}

events. The mean values given here, then represent a maximum estimation.

Finally, to estimate the area where the flux calculation at Trainou Tower is valid, we use the wind velocities during the nocturnal inversion period. The maximum wind speed at $180 \mathrm{~m}$ is found to be $5 \mathrm{~m} \mathrm{~s}^{-1}$, leading to a catchment area with a radius of about $90 \mathrm{~km}$ around the tower. This result implies that the deposition velocity we measure is valid for an area that includes a mixing of forest, fields, villages and the city of Orléans. The mean hydrogen deposition velocities calculated with the box model and with the Radon-Tracer-Method agree well with each other.

As shown in Table 1, these values also agree well with other studies conducted in suburban and rural areas. Indeed, the values lie close to those found at Gif-sur-Yvette of $2.4 \pm 1.3 \times$ $10^{-2} \mathrm{~cm} \mathrm{~s}^{-1}$, at Heidelberg of $3.0 \pm 0.7 \times 10^{-2} \mathrm{~cm} \mathrm{~s}^{-1}$ (Hammer and Levin, 2009) or at Bristol $\left(2.2 \pm 1.5 \times 10^{-2} \mathrm{~cm} \mathrm{~s}^{-1}\right.$, Grant et al., 2010b). These values are in the low range of those from Yonemura et al. (2000), which were measured with a flux chamber in a field and in a forest in Japan but are consistent with each other within the uncertainties. The timing of the seasonal cycle agrees well with the other studies (Hammer and Levin, 2009; Yver et al., 2009). The amplitude of the seasonal cycle is similar to the one observed at Gif-sur-Yvette $( \pm 40 \%)$ but is about two times lower than that observed at Heidelberg $( \pm 25 \%)$.

\section{3. $\mathrm{H}_{2} / \mathrm{CO}$ correlation during winter months}

As already shown in Fig. 3, the mean diurnal cycles of $\mathrm{H}_{2}$ and $\mathrm{CO}$ vary greatly for all sampling heights. During winter, however, we observe several pollution events with strong correlation between $\mathrm{H}_{2}$ and $\mathrm{CO}$ (Fig. 1). For each day (00:00 to 23:59 UTC), we calculate the correlation between $\mathrm{H}_{2}$ and $\mathrm{CO}$ at the $50 \mathrm{~m}$ given by the slope of the linear regression between the two gas hourly mean mixing ratios using a weighted least-squares algorithm. As in Yver et al. (2009), since this calculated ratio corresponds to the

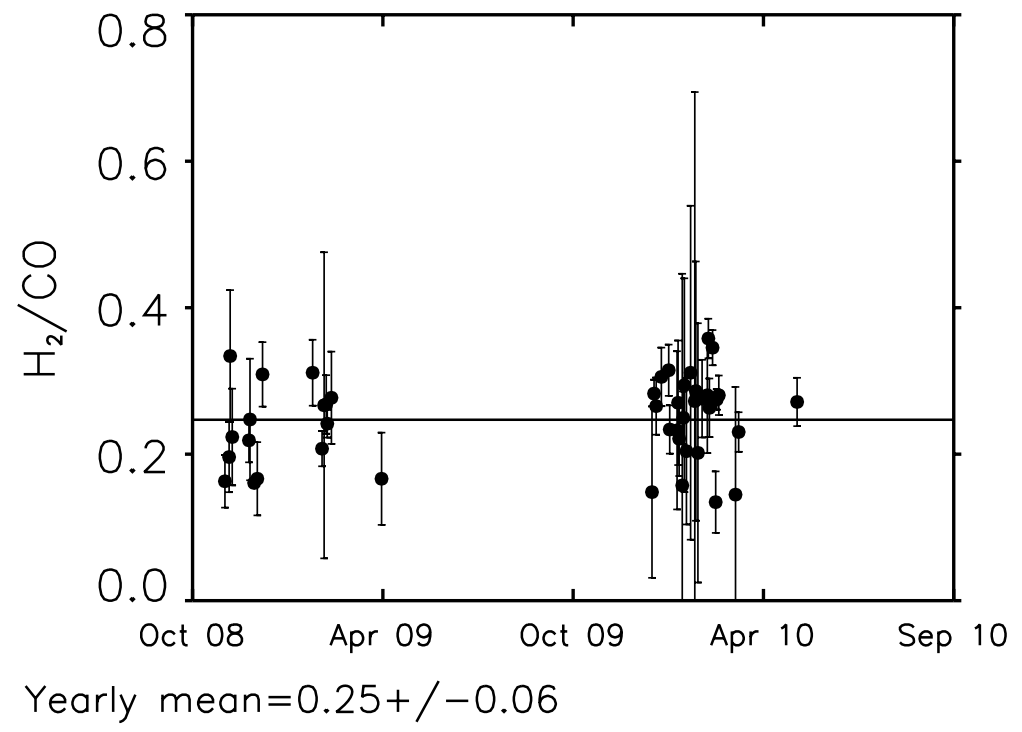

Fig. 6. $\mathrm{H}_{2} / \mathrm{CO}$ ratios calculated for the $50 \mathrm{~m}$ height from the daily linear regression between hourly mean $\mathrm{H}_{2}$ and $\mathrm{CO}$ mixing ratios. Only regressions with $R^{2}$ greater than 0.6 are shown. 
Table 2. Hydrogen to carbon monoxide ratio.

\begin{tabular}{llll}
\hline Study & Duration & Location and period & Molar $\mathrm{H}_{2} / \mathrm{CO}$ (corrected) \\
\hline Hammer et al. (2009) & $2005-2007$ & Heidelberg urban setting, rush hours & $0.46 \pm 0.07$ \\
Hammer et al. (2009) & $2005-2007$ & Heidelberg urban setting, pollution events & $0.48 \pm 0.07$ \\
Yver et al. (2009) & $2006-2009$ & Gif-sur-Yvette, rush hour & $0.47 \pm 0.09$ \\
Aalto et al. (2009) & $2007-2008$ & Helsinki, rush hour & $0.49 \pm 0.07$ \\
This study & $2008-2010$ & Trainou, pollution events & $0.27 \pm 0.06$ \\
\hline
\end{tabular}

slope of the linear regression of the hourly mean mixing ratios, it is independent of the seasonal variations. Figure 6 presents all $\mathrm{H}_{2} / \mathrm{CO}$ ratios during pollution events with a coefficient of determination $\left(R^{2}\right)$ higher than 0.6 and a correlation error below $50 \%$. Most of the $\mathrm{H}_{2} / \mathrm{CO}$ ratios fulfilling the above criteria are calculated during wintertime. Thirty-three events are used to calculate a mean $\mathrm{H}_{2} / \mathrm{CO}$ of $0.22 \pm 0.06$, without correction for the soil sink. Indeed, during the day, the deposition process is still going on, leading to a measured $\mathrm{H}_{2}$ mixing ratio lower than the mixing ratio directly coming from the car exhausts. Therefore, it needs to be taken into account to properly estimate the ratios of anthropogenic emissions (Hammer et al., 2009). At Gif-surYvette, we used the total $\mathrm{H}_{2}$ flux as in the equation below (Yver et al., 2009):

$$
\frac{C_{\mathrm{H}_{2}}}{C_{C O}}=\frac{C_{\mathrm{H}_{2} \text { tot }}}{C_{\mathrm{CO}}}\left(1-\frac{J_{\mathrm{H}_{2} \text { sink }}}{J_{\mathrm{H}_{2} \text { tot }}}\right),
$$

where $\frac{C_{\mathrm{H}_{2} \text { tot }}}{C_{\mathrm{CO}}}$ is the ratio directly calculated each day with the linear regression, $J_{\mathrm{H}_{2} \text { sink }}=-4.08 \times 10^{-5} \mathrm{~g} \mathrm{~m}^{-2} \mathrm{~h}^{-1}$ is the soil uptake as estimated at Gif-sur-Yvette and $J_{\mathrm{H}_{2} \text { tot }}$ is the total $\mathrm{H}_{2}$ flux composed of a negative flux from the soil uptake and of a positive flux from the emissions. At Trainou Tower, it is difficult to estimate the total flux of $\mathrm{H}_{2}$ with the Radon-Tracer-Method as the period covers a whole day. Indeed, $\mathrm{H}_{2}$ and ${ }^{222} \mathrm{Rn}$ are never correlated for such a long period. We therefore use the $\mathrm{CO}$ flux $J_{\mathrm{CO}_{\mathrm{tot}}}$ :

$$
-\frac{C_{\mathrm{H}_{2}}}{C_{\mathrm{CO}}}=\frac{C_{\mathrm{H}_{2} \text { tot }}}{C_{\mathrm{CO}}}-\frac{J_{\mathrm{H}_{2} \text { sink }}}{J_{\mathrm{CO}}} .
$$

As $\mathrm{CO}$ and ${ }^{222} \mathrm{Rn}$ are, like $\mathrm{H}_{2}$ and ${ }^{222} \mathrm{Rn}$, not correlated for a long period, we estimate the $\mathrm{CO}$ daily flux around Trainou Tower with the inventory from Thiruchittampalam and Köble (2008). The inferred mean CO flux of $\approx 8 \times 10^{-4} \mathrm{~g} \mathrm{~m}^{-2} \mathrm{~h}^{-1}$ combined with the mean winter $\mathrm{H}_{2}$ soil uptake flux of $-2.6 \times$ $10^{-5} \mathrm{~g} \mathrm{~m}^{-2} \mathrm{~h}^{-1}$ leads to a correction of $+14 \%$ of the previous $\mathrm{H}_{2} / \mathrm{CO}$ ratio. After applying this hydrogen deposition correction, the ratio amounts to $0.25 \pm 0.06$. Figure 6 shows the $\mathrm{H}_{2} / \mathrm{CO}$ ratio varying between 0.1 and 0.4 with no seasonal pattern. The main uncertainties come from the $\mathrm{H}_{2} / \mathrm{CO}$ slope errors (15\%) and from the correction for the $\mathrm{H}_{2}$ deposition (the errors concerning the deposition flux are estimated to be approximately $25 \%$ in Yver et al., 2009). The overall uncertainty, then, amounts to $\approx 35 \%$. Table 2 summarizes the $\mathrm{H}_{2} / \mathrm{CO}$ ratios from different anthropogenic sources reported in the literature. The $\mathrm{H}_{2} / \mathrm{CO}$ ratio at Trainou Tower is lower than all ratios previously reported (Aalto et al., 2009; Hammer et al., 2009; Yver et al., 2009) during traffic peaks. As previously shown, there is no apparent correlation between traffic and the $\mathrm{H}_{2}$ and $\mathrm{CO}$ mixing ratios in the diurnal cycles at Trainou.

Contrary to Gif-sur-Yvette and the others suburban sites, we can not easily separate the contribution from the different sources at Trainou. It seems that we measure a mix of emissions from traffic, residential heating and wood burning. Indeed, the $\mathrm{H}_{2} / \mathrm{CO}$ ratio from residential heating and wood burning are lower than the ratio from traffic. The ratio from residential heating is believed to be between and 0 and 0.15 (M.K. Vollmer, personal communication, 2009). For biomass burning, Hauglustaine and Ehhalt (2002) proposed a value of 0.28 and Price et al. (2007) of 0.29 and for biofuels of 0.32 . The winter ratio that we have calculated is then probably the result of the combination of all these sources, especially as in winter, residential heating and wood burning play a more important role than in summer.

\section{Conclusion}

Measurements of $\mathrm{H}_{2}$ and $\mathrm{CO}$ have been performed semicontinuously at the tall tower of Trainou (at 50, 100 and $180 \mathrm{~m}$ agl) since October 2008 and measurements of ${ }^{222} \mathrm{Rn}$ have been conducted since May 2009. We observe seasonal cycles for $\mathrm{H}_{2}$ and $\mathrm{CO}$ with baseline variations similar to those of the baseline at Gif-sur-Yvette and to the northern hemispheric background mixing ratios from Mace Head. We estimate the $\mathrm{H}_{2}$ deposition velocity with a box model approach and with the Radon-TracerMethod. Both methods lead to similar results with a mean deposition velocity around $2.6 \times 10^{-2} \mathrm{~cm} \mathrm{~s}^{-1}$. The box model selects sparse events and no seasonal cycle is apparent. With the Radon-Tracer-Method, however, we find a seasonal cycle with an amplitude of $40 \%$. In contrast to Gif-sur-Yvette, there is no diurnal cycle correlated with traffic peak in the morning or afternoon but in winter, we sometimes observe a high correlation of $\mathrm{H}_{2}$ and $\mathrm{CO}$ with a mean ratio of 0.25 . This value, which is lower than the ratio measured for the anthropogenic emissions from transport is representative of the variety of sources that have an influence on the concentrations at Trainou. Also in contrast to Gif-sur-Yvette, there is no predominance of transport but a mix of different sources.

This study has shown that tall tower measurements contain local to regional information on the sources and sinks of trace 
gases. Through the vertical gradient we can apply an additional method to access the soil uptake. This study also confirms the mean value of $\mathrm{H}_{2}$ soil uptake for suburban area in the midnorthern latitudes.

\section{Acknowledgments}

We gratefully thank Mathilde Grand, Claire Peureux and Vincent Bazantay for performing the flasks analyses, Eric Parmentié from IPGP for the weekly maintenance of the Trainou tower site, Franois Truong and Cyrille Vuillemin for the installation of the radon analyser and Bernard Aumont for the idea of using a simple box model approach. The RAMCES network is funded by INSU and CEA. This work was partly funded by EUROHYDROS.

\section{References}

Aalto, T., Lallo, M., Hatakka, J. and Laurila, T. 2009. Atmospheric hydrogen variations and traffic emissions at an urban site in finland. Atmos. Chem. Phys. 9, 7387-7396.

Barnes, D. H., Wofsy, S. C., Fehlau, B. P., Gottlieb, E. W., Elkins, J. W., and co-authors. 2003. Hydrogen in the atmosphere: observations above a forest canopy in a polluted environment. J. Geophys. Res. D. Atmos. 108(D6), 4197-4206.

Biraud, S., Ciais, P., Ramonet, M., Simmonds, P., Kazan, V., and coauthors. 2000. European greenhouse gas emissions estimated from continuous atmospheric measurements and radon 222 at mace head, ireland. J. Geophys. Res. D. Atmos. 105, 1351-1366.

DREC 2007. Trafic routier en région centre. URL: http://www. centre.equipement.gouv.fr/article.php3?id_article $=499$

Ehhalt, D. H. and Rohrer, F. 2009. The tropospheric cycle of $\mathrm{h}_{2}$ : a critical review. Tellus 61B, 500-535.

Grant, A., Witham, C., Simmonds, P., Manning, A. and O'Doherty, S. 2010a. A 15 year record of high-frequency, in situ measurements of hydrogen at mace head, ireland. Atmos. Chem. Phys. 10(3), 1203-1214.

Grant, A., Stanley, K. F., Henshaw, S. J., Shallcross, D. E. and O'Doherty, S. 2010b. High-frequency urban measurements of molecular hydrogen and carbon monoxide in the united kingdom. Atmos. Chem. Phys. 10(10), 4715-4724.

Hammer, S. and Levin, I. 2009. Seasonal variation of the molecular hydrogen uptake by soils inferred from continuous atmospheric observations in heidelberg, southwest germany. Tellus 61B, 556-565.

Hammer, S., Vogel, F., Kaul, M. and Levin, I. 2009. The $\mathrm{H}_{2} / \mathrm{CO}$ ratio of emissions from combustion sources: comparison of top-down with bottom-up measurements in southwest germany. Tellus 61B, 547-555.

Hauglustaine, D. A. and Ehhalt, D. H. 2002. A three-dimensional model of molecular hydrogen in the troposphere. J. Geophys. Res. 107(D17), 4330.

Jacobson, M. Z. 2008. Effects of wind-powered hydrogen fuel cell vehicles on stratospheric ozone and global climate. Geophys. Res. Lett. 35(19).

Jordan, A. and Steinberg, B. 2010. Calibration of atmospheric hydrogen measurements. Atmos. Meas. Techn. (amt-2010-146).
Jutzi, S. 2001. Verteilung der boden-222 radon-exhalation in Europa, $\mathrm{Ph}$.D. Thesis. Institut für Umweltphysik, University of Heidelberg, Germany.

Keeling, C. D., Bacastow, R. B., Bain-Bridge, A. E., Ekdahl, C. A., Guenther, P. R., and co-authors. 1976. Atmospheric carbon dioxide variations at mauna loa observatory, hawaii. Tellus 28B, 538.

Levin, I., Glatzel-Mattheier, H., Marik, T., Cuntz, M., Schmidt, M., and co-authors. 1999. Verification of German methane emission inventories and their recent changes based on atmospheric observations. J. Geophys. Res. 104(D3).

Messager, C. 2007. Greenhouse gases regional fluxes estimated from atmospheric measurements (in French), Ph.D Thesis. Université de Versailles Saint-Quentin, Versailles, France. URL: tel.archivesouvertes.fr/docs/00/16/47/20/PDF/ these_messager_2007.pdf

Novelli, P. C., Elkins, J. W. and Steele, L. P. 1991. The development and evaluation of a gravimetric reference scale for measurements of atmospheric carbon monoxide. J. Geophys. Res. 96(D7).

Novelli, P. C., Lang, P. M., Masarie, K. A., Hurst, D. F., Myers, R., and co-authors. 1999. Molecular hydrogen in the troposphere-global distribution and budget. J. Geophys. Res. 104(D23), 30 427-30 444.

Price, H., Jaegl(c), L., Rice, A., Quay, P., Novelli, P. C., and co-authors. 2007. Global budget of molecular hydrogen and its deuterium content: constraints from ground station, cruise, and aircraft observations. $J$. Geophys. Res. 112(D22), 22108.

Sanderson, M. G., Collins, W. J., Derwent, R. G. and Johnson, C. E. 2003. Simulation of global hydrogen levels using a lagrangian threedimensional model. J. Atmos. Chem. 46(1), 15-28.

Schery, S. D., Gaeddert, D. H. and Wilkening, M. H. 1984. Factors affecting exhalation of radon from a gravelly sandy loam. J. Geophys. Res. D. Atmos. 89(5), 7299-7309.

Schmidt, M., Glatzel-Mattheier, H., Sartorius, H., Worthy, D. E. and Levin, I. 2001. Western European n 2 o emissions-a top-down approach based on atmospheric observations. J. Geophys. Res. 106, 5507-5516.

Schmidt, M., Graul, R., Sartorius, H. and Levin, I. 2003. The schauinsland CO 2 record: 30 years of continental observations and their implications for the variability of the European $\mathrm{CO} 2$ budget. J. Geophys. Res. 108(D19), 4619.

Schmitt, S., Hanselmann, A., Wollschläger, U., Hammer, S. and Levin, I. 2009. Investigation of parameters controlling the soil sink of atmospheric molecular hydrogen. Tellus 61B(2), 416-423.

Schultz, M. G., Diehl, T., Brasseur, G. P. and Zittel, W. 2003. Air pollution and climate-forcing impacts of a global hydrogen economy. Science 302(5645), 624-627. doi: 10.1126/science.1089527.

Steinbacher, M., Fischer, A., Vollmer, M. K., Buchmann, B., Reimann, S., and co-authors. 2007. Perennial observations of molecular hydrogen (H2) at a suburban site in Switzerland. Atmos. Environ. 41(10), 2111-2124.

Szegvary, T., Conen, F. and Ciais, P. 2008. European 222rn inventory for applied atmospheric studies. Atmos. Environ. 43(8), 1536-1539.

Thiruchittampalam, B. and Köble, R. 2008. European emissions map. Institute of Energy, Economics and the Rational Use of Energy (IER); University of Stuttgart. URL: http://carboeurope.ier.unistuttgart.de/

Tromp, T. K., Shia, R., Allen, M., Eiler, J. M. and Yung, Y. L. 2003. Potential environmental impact of a hydrogen economy on the stratosphere. Science 300(5626), 1740-1742. 
Whittlestone, S. and Zahorowski, W. 1998. Baseline 222 Rn detectors for shipboard use: Development and deployment in the first aerosol characterisation experiment (ACE 1). J. Geophys. Res. 103, 16743-16751.

Xiao, X., Prinn, R., Simmonds, P., Steele, L., Novelli, P., and co-authors. 2007. Optimal estimation of the soil uptake rate of molecular hydrogen from the advanced global atmospheric gases experiment and other measurements. J. Geophys. Res. 112(D7).

Yonemura, S., Kawashima, S. and Tsuruta, H. 2000. Carbon monoxide, hydrogen, and methane uptake by soils in a temperate arable field and a forest. J. Geophys. Res. 105, 14347-14362.
Yver, C., Schmidt, M., Bousquet, P., Zahorowski, W. and Ramonet, M. 2009. Estimation of the molecular hydrogen soil uptake and traffic emissions at a suburban site near Paris through hydrogen, carbon monoxide, and radon-222 semicontinuous measurements. J. Geophys. Res.-Atmos. 114(D18), D18304.

Zahorowski, W., Chambers, S. D. and Henderson-Sellers, A. 2004. Ground based radon-222 observations and their application to atmospheric studies. J. Environ. Radioactivity 76(1-2), 3-33.

Zobler, L. 1986. A world soil file for global climate modelling. NASA Tech. Memorandum 87802, 32. 